\title{
Financial Hurdles in Small Business Enterprises in Kathmandu Valley
}

\section{Dipak Bahadur Adhikari', Bimal Shakya2 ${ }^{2}$, Niranjan Devkota ${ }^{2 *}$, Dipendra Karki ${ }^{3}$, Udbodh Bhandari², Seeprata Parajuli², Udaya Raj Paudel ${ }^{2}$}

${ }^{1}$ Patan Multiple Campus, Tribhuvan University, Patandhoka, Lalitpur, Nepal

${ }^{2}$ Quest International College, Pokhara University, Gwarko, Lalitpur, Nepal

${ }^{3}$ Nepal Commerce Campus, Tribhuvan University, Minbhawan, Kathmandu, Nepal

Email: *niranjandevkota@gmail.com

How to cite this paper: Adhikari, D. B., Shakya, B., Devkota, N., Karki, D., Bhandari, U., Parajuli, S., \& Paudel, U. R. (2021). Financial Hurdles in Small Business Enterprises in Kathmandu Valley. Modern Economy, 12, 1105-1118.

https://doi.org/10.4236/me.2021.126058

Received: May 11, 2021

Accepted: June 25, 2021

Published: June 28, 2021

Copyright () 2021 by author(s) and Scientific Research Publishing Inc. This work is licensed under the Creative Commons Attribution International License (CC BY 4.0). http://creativecommons.org/licenses/by/4.0/

\begin{abstract}
Small businesses are the backbone of the economy in developing countries like Nepal. In such circumstances, small-scale businesses are more appropriate ones in the process of the economic development of the nation. This study pursues to contribute to the experiential understanding of the important and financial hurdles in small business enterprises in Nepal. This paper is based on primary data which are collected from 403 entrepreneurs in small business enterprises. The survey shows more than ninety percent of respondents feel different factors constraining the financial aspect of small businesses while a negligible percent of respondents do not feel any challenges.
\end{abstract}

\section{Keywords}

Small \& Medium Scale Industries, Business, Financial Hurdles, Financial Institutions, Kathmandu Valley

\section{Background}

Small and medium-sized firms dominate the economy in terms of employment and the number of companies, yet their full potential remains remarkably untapped (Schlogl, 2004; Devkota et al., 2020a). They have diversified the country's monetary base and provided it with the occasion of responding to a diversity of market conditions. The contribution of SMEs (Small and Medium scale industries) has created jobs and hence reduced the rate of unemployment (Agbenyo, 2015; Devkota et al., 2020b). Private ventures are considered as one of the mainstays of the financial structure, especially in the creating nations. 
Nepal is a country well known for craftsmanship. From the earliest starting point up to the mid-nineteenth century, the leaders of the nation advanced national businesses and exchange to different proportions of creation, advancement, and support (Ghimire, 2012; Devkota et al., 2020a). Nepal is a landlocked and least developed nation. In such circumstances, small-scale undertakings are more appropriate businesses in the way of the mechanical advancement process in the nation (Adhikari et al., 2021). Such business can be run with the utilization of nearby assets, neighborhood abilities, and locally accessible crude materials also, merchandise can be sold inside nearby or neighbor showcase. It assists with creating additional income, diminishes joblessness issues, and legitimate utilization of relaxation time after gathering of harvests and before time frames of development of yields. In this manner, miniaturized scale venture assumes an indispensable job in the setting of business advancement segments just as mechanical improvement part in the nation (Karki, 2018).

SMEs contribute fundamentally to a country's economy-producing, work age, fares, and GDP development (Devkota et al., 2020a). In developing nations, SMEs contribute around $40 \%$ of the all-out GDP and $60 \%$ of the complete work (Ndiaye et al., 2018). In like manner, in Nepal, as Nepal Rastra Bank (NRB), SMEs contribute around $22 \%$ of the GDP and create around 17 lakh businesses. Before the finish of the financial year 2074/75, there were 275,433 SMEs enrolled in Nepal (NRB, 2019). They are banks and budgetary organizations, cooperatives, investments/private values, or capital markets. One could likewise select to fund the endeavor all alone. Among these, the financial segment is noted as the fundamental wellspring of SME financing in Nepal. The absence of access to innovation is majorly affecting the fare capacity of most SMEs (Ghimire, 2012).

The least developed countries (LDC) like Nepal have traditional practices in the scenario of small business enterprises (Paudel \& Devkota, 2018, 2020). However, small businesses require low measure of venture, low innovation, and little market in comparison to the medium scale enterprises. The significance of small and medium-sized ventures (SMEs) in adding to job creation and monetary development is currently broadly acknowledged in both developed and developing countries (Karadag, 2015). As indicated by the report of Role of worker's guilds in miniaturized scale and little undertakings in Nepal the development of MSE part in the urban areas comprising of the assembling, development, exchange and lodgings, transportation, and correspondence are evident from the fact that the extent of individuals associated with this division, which was 7.2 percent in 1991, has expanded to 17.2 percent in 1999. Whereas, the country-based exercises like farming, fishery, ranger service, mining, and quarrying and network and social services have diminished from 92.8 percent in 1991 to 82.8 percent in 1999. From the financial development viewpoint, SMEs give an assortment of advantages (Zaborek \& Mazur, 2019). As per Kongolo (2010), SMEs play noteworthy commitment in the change of agribusiness drove economies to mechanical ones outfitting plain open doors for handling exercises 
which can create an economical wellspring of income and upgrade the advancement procedure. SMEs shore up the extension of fundamental profitable ability. They help to ingest beneficial assets at all degrees of the economy and add to the arrangement of flexible monetary frameworks in which little and enormous firms are interlinked (Ghimire, 2011).

However, the study of financial hurdles for small business enterprises is a noble area though various research has been conducted in the field of small business enterprises. Somehow, this problem was addressed by microfinance, providing financial assistance to small business owners (Adhikari and Shrestha, 2013). Adhikari (2019) further emphasized microfinance also a means of finance for SMEs and self-employment. But it is not sufficient. Hence this study covers the objective of accessing the information regarding the impact of financial hurdles in small business enterprises in Kathmandu Valley which further contribute to solving some aspects of economic and social problems in Kathmandu valley.

Upon completion of this study, it will benefit various small business enterprises to overcome a certain aspect of financial issues which will help to get further insights into the study area. Further, the study can also be useful to policy makers and authorities working in the field of small business enterprise for formulating appropriate guidelines and strategies in the respective field. This study is the first study related to financial hurdles and its impact on small business enterprises in context of Nepalese study. It covers objective of accessing the information regarding the impact of financial hurdles in small business enterprises in Kathmandu Valley which further contribute to solving some aspects of economic and social problems in Kathmandu valley.

Despite of significances, there are certain limitations of this study as well. As the study was first of a kind important variables are tried to be incorporated, however, it might have missed some which can be included in later studies. Also, due to time constraints Kathmandu valley was selected for the study however, future research could cover greater area for better output. Similarly, only descriptive analysis is made on the study further research can include empirical evidences to make study results more effective. Thus, the study will be beneficial to future researchers as this study will support them to carry their study further providing guidelines and insights on various literatures related to the study.

The further part of this paper is arranged in the following structure: The literature review occurs in section two. The Methodology is discussed in section three. Section four covers the result and discussion. Similarly, the fifth section includes the conclusion.

\section{Literature Review}

It was found that most SMEs face difficulties as the arrangement and authoritative difficulties pursued by the advertising and money related-issues (Christina, Neelufer, \& Al Amri, 2014). The examination centers on failure to distribute a 
similar nature of money related data as those huge firms and accordingly can't give evaluated fiscal report. Another issue has to do with the deficient capital base of most SMEs in the nation to meet the guarantee necessity by the banks before acknowledge is given just as low degree of $R \& D$ uses, and inadequate utilization of data innovation and gives solutions for moderating them (Yoshino, 2016). The examination inspects the utilization of monetary data in little organizations, as money-related administration is basic to their prosperity and endurance (Collis \& Jarvis, 2002). In this article, we draw upon insights from our years as fraud investigators to offer seven practical recommendations to help small business leaders prevent and detect fraud in this unique environment. These strategies can help even the smallest company make a big difference when it comes to fraud risk management (Hess \& Cottrell, 2016).

The SME sector has contributed immensely to job creation, poverty alleviation, and assisting in the prosperity of the nation. In addition to the above, SMEs are generally inexpensive to start and have the potential to generate massive economic growth (Ryan, 2017). The importance of small and medium enterprises (SMEs) in the process of transition from a centrally planned to a market economy is now widely recognized in the literature (Savych, 2002). The significance of SMEs is underlined by the fact they account for about 90 percent of enterprises and 60 percent of employment at the global level (Mutandwa, Taremwa, \& Tubanambazi, 2015). Numerous speculations have raised the issue on the financing for small and medium enterprises (SMEs), implying that there are a decent number of SMEs when offered access to credit could utilize it gainfully to develop their organizations yet can't get credit from the formal money related framework, due to the failure of the SMEs to meet the stringent prerequisite of these monetary institutions. The issue of absence of credit to SMEs can be taken a gander at from two fronts: the budgetary establishments and the SMEs administrators (Ackah \& Vuvor, 2010).

The terms SME and miniaturized scale and little endeavors (MSE) are much of the time utilized reciprocally in writing (Mutandwa et al., 2015). Omar, Arokiasamy, \& Ismail (2009) in their article analyze the foundation and difficulties faced by SMEs which assume an essential job in the country's development. The uniqueness of this paper is the accentuation on the human asset advancement viewpoint which is significant for SMEs to advance and be focused on. At last, this article maps out how future research can be progressively touchy to how SMEs really build up their possession of human asset improvement for future advancement.

There will be full-scale monetary elements that any business faces. If the SME isn't well furnished to manage these elements, it will bring about the disappointment of the business. Notwithstanding outer components, there would likewise be inner shortages which would hamper the accomplishment of an SME (Ryan, 2017). Study discoveries show that SMEs need the monetary capacity to create the amount of their item to serve an enormous network. Further discove- 
ries show that SMEs face difficulties to get to universal advertising uninformed of guidelines and principles, with poor comprehension of purchaser's needs and administrations, absence of basic pioneering abilities, and frail systems administration structures to enter into worldwide promoting. The investigation in this manner suggests the improvement of data that is accessible to SME proprietors; to the legislature and different accomplices profit availability to monetary offices with sensible loan fee of return, support more promotions and utilization of exceptional innovation for business and worldwide showcasing gauges through workshops, and trainings on enterprise, and systems administration structures for fare and import of products and ventures (Kazimoto, 2014).

From the above literature, it can be stated that though small business enterprises are prospering there still are some glitches from the administrative point of view as well as client's point of view. Certain factors like capital, technologies, skill manpower are still the matter of issue in small business enterprises therefore to understand and study about such matters this study can provide insight by addressing certain issues like major financial hurdles being faced by small business enterprises, determinants and factors causing such hurdles to small business enterprises and the ways to manage such challenges.

\section{Methods}

\section{Sample Method and Study Area}

The study area for this research is the Kathmandu valley of Nepal. Nepal has 77 districts, and among the 77 districts, 3 districts include in Kathmandu valley (Kathmandu, Bhaktapur, and Lalitpur) situated in Bagmati province were taken for the study area of this research. Kathmandu Valley lies at 1300 meters above the sea level and is located between latitudes $27^{\circ} 32^{\prime} 13^{\prime \prime}$ and $27^{\circ} 49^{\prime} 10^{\prime \prime}$ north and longitudes $85^{\circ} 11^{\prime} 31^{\prime \prime}$ and $85^{\circ} 31^{\prime} 38^{\prime \prime}$ east. Its three districts, Kathmandu, Lalitpur, and Bhaktapur, cover an area of 899 square kilometers, whereas the area of the valley as a whole is 665 square kilometers. The valley encloses the entire area of Bhaktapur district, $85 \%$ of Kathmandu district, and $50 \%$ of Lalitpur district.

Kathmandu is capital city of Nepal. Being the capital of nation most of the small and large business are centered in the valley itself holding one of the largest population status of the country where people from different regions migrate for better and greater job opportunity. Therefore, Kathmandu valley is chosen as the area of the study in sighting that the sample would represent people around different places and conducting small business in various sectors providing us with reliable information that can be effective for the study.

The nation has seen an empowering development of smaller and medium enterprises (SMEs) over the most recent multi decade as the number of such endeavors expanded to 400,000 in the middle of $2006 / 07$ to $2015 / 16$ when contrasted with 69,431 till financial 2005-2006, as indicated by the Department of Cottage and Small Industries (DCSI). Even though the modern atmosphere had been breaking down and huge ventures were antagonistically influenced because 
of different reasons like political insecurity, power blackout, and work bothers, among others, in the most recent decade, the quantity of MSMEs developed exponentially in a similar period (Acharya, 2017).

The sample size can be derived by computing following formula $n=Z^{2} \mathrm{pq} /{ }^{2}$ (Devkota et al., 2021). Where, $n=$ sample size required for study, standard tabulated value for $5 \%$ level of significance $=z, p=$ Prevalence of customer awareness on banking communication, $q=1-p$ and $l=$ degree of accuracy, usually set at 0.05 level. So, total population for the study $n=z 2 p q / d^{2}=(1.96)^{2} \times 0.5 \times$ $0.5 /(0.05)^{2}=384.16$. Non-response error $5 \%$, i.e. $384.16 \times 5 / 100=19.208$. Thus, sample size taken for study was $(384.16+19.208)=403.368(\approx 403)$.

In this study, the key informant interview (KII) \& structured questionnaire were used. 5-point likert scale was used while developing questionnaire classifying questions into various sections as per the need of study and model deployed. Small business enterprises survey and key informant interviews were primary sources used in the study. To get quantitative data from individual venture, the owner's survey was conducted. A questionnaire has been prepared \& implemented for the data collection. For this research quantitative analysis primary data was gathered. Once the data were collected, they were edited and sorted by using the statistical tool. For analysis, descriptive techniques were used and data were analyzed using Microsoft excel.

\section{Result and Discussion}

\subsection{Description of Socio-Demographic Characteristics}

The age of respondents was divided into five groups among which majority one-third of respondents are of age group 25 - 35. Similarly, one-fourth of respondents are of age 15 - 25 and just a negligible percent of respondents from old age. It reveals that the small and medium scale business is dominated by the prime working-age population. The sex factor has been chosen in socio-demographic characteristics as it helps us to know that both males and females are almost equally involved in small businesses. This research shows that sex composition for this research is $45 \%$ female and $55 \%$ male which indicates that participation of males in giving information on this issue is more than females. In opposition to this situation of male-female proportion, Minniti and Naudé (2010) argued about the increasing number of female entrepreneurs in developing countries and the need to create jobs for a predominantly young population. More than half of the respondents are married (Figure 1).

The education level of respondents indicates that the education level of respondents is very high. The majority of the respondents in this study cover people having no education at all to education above master's level. In this regard, more respondents (both male and female) have university degree. Whereas, higher education is dominated by female respondents and school education is slightly higher in the case of male respondents. Education is very crucial in enhancing knowledge for business (Figure 2). 


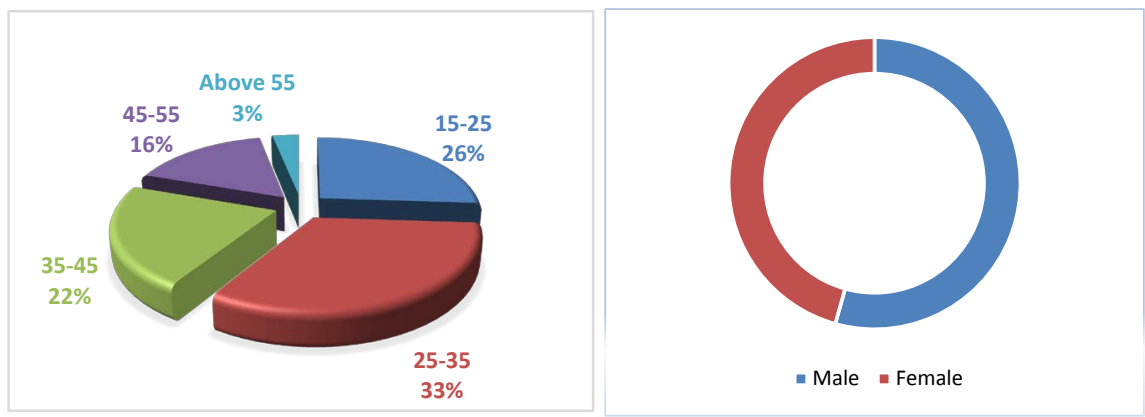

Figure 1. Age and sex of respondents. Source: Field Survey.

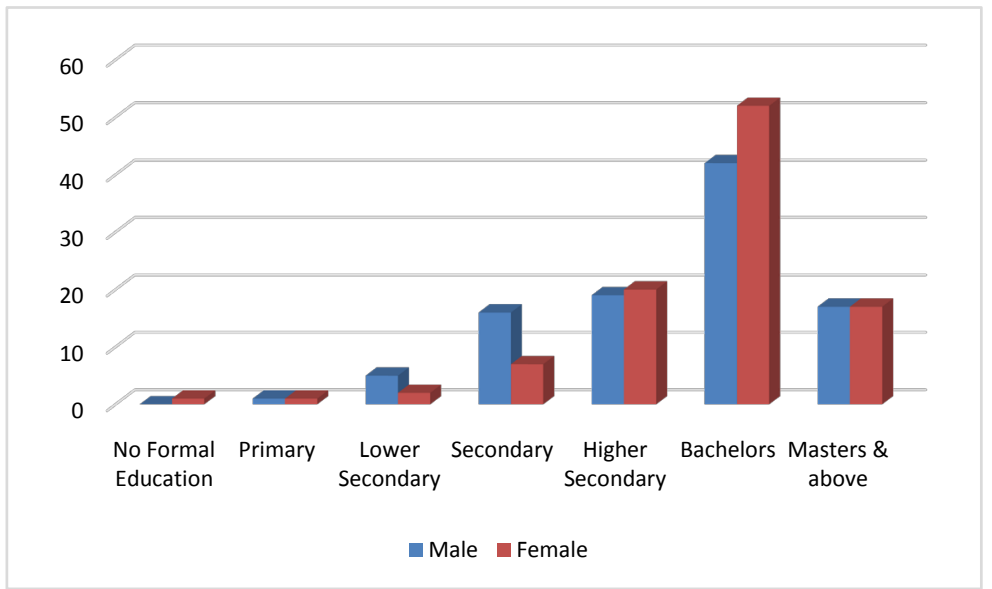

Figure 2. Education level. Source: Field Survey.

\subsection{Information Regarding Small Business}

The informational level of people on small business describes how many respondents are familiar with doing business in Nepal. It also explains various financial problems and different hurdles that come in small businesses. There may be various statuses of various respondents. Some may have a good understanding of the operation of small business whereas some respondents have little knowledge and interest respectively. So, this section clearly explains the current understanding of small businesses in Kathmandu Valley.

From the data, it is found that out of 403 respondents, 261 respondents work in a sole proprietor business entity and 142 respondents work in a partnership business entity. It is also found that out of total respondents of 403, 38 percent respondents have experience in their business up to 2 years, 32 percent have experience in their business up to 4 years, 20 percent respondents have experience in their business up to 6 years, 7 percent have experience in their business up to 8 years, and 3 percent respondents have experience in their business above 8 years. This shows that most of the respondents are newcomers to the market. Those who work a long time in small business left and seem involved in other sectors. In this regard, several studies have shown that thousands of small businesses kickstart each year, but a considerable number of them fail before or during their first year of operation, with the majority closing down before their 
second year (Almus, 2004; Persson, 2004). Out of total respondents of 403, 339 respondents keep a record of their business transaction manually that is by writing them down on registers while 128 respondents keep their records systematically in the computerized system through the use of various applications like word and excel. This shows that most of the respondents still use the traditional system of record keeping.

Among the respondents, 92 respondents are involved in the food and grocery business, 25 respondents are involved in the fruits and vegetable business, 31 respondents are involved in the furniture business, 50 are in the plastic business, 27 are in the stationery business, 128 in the clothing and fancy business, whereas 50 respondents are involved in other businesses as handicrafts, restaurants, artistic sectors, etc. From this data, it can be concluded that most of the respondents are involved in the clothing business. In this context, Hatten (2012) argues that small businesses include the activities of a stay-at-home parent who provides daycare for children whose parents are not present, factory workers who engage in after-hours deliveries, and owners of fast-food restaurants.

\subsection{Loan and the Rental Situation in Small Business}

This section covers the loan history of the respondents. From the survey, 203 respondents have taken loan, whereas the rest of the respondents i.e., 200 respondents haven't taken the loan and are operating business on their own. In such circumstances, Lappalainen and Niskanen (2013) argue that bank loans, which are an essential cofactor for small businesses, are too difficult for small business owners to receive in developing countries. Among 203 respondents who have taken loans, 15 respondents have taken formal loans from banks and other financial institutions, whereas 182 respondents have taken loans of informal nature i.e., from friends, families, and relatives to operate their business, whereas 6 respondents have taken both formal as well as informal loans. Furthermore, a substantial body of research has argued that a lack of access to funding is linked to very strict financial policies and bank practices, placing collateral as the primary requirement for securing bank loans, causing small businesses to suffer from what is known as financial illusion (Mambula, 2002; Moses, 2010; Kennedy et al., 2006; Moses and Adebisi, 2013). In this section, the rental status of respondents is discussed from the survey. 75 respondents pay rent for the operation of their business whereas the rest of the 328 respondents doesn't have to pay rent which means that they operate their business from their home with the available space they have (Figure 3 ).

\subsection{Challenges Associated with Financial Hurdles in Small Business}

Small business has a great scope of potential growth in terms of Kathmandu Valley. Small business is a very important aspect for day-to-day operation of human life. It has both benefits with a whole lot of challenges in such prospect. It depends upon people how they handle such responsibility and take over such 


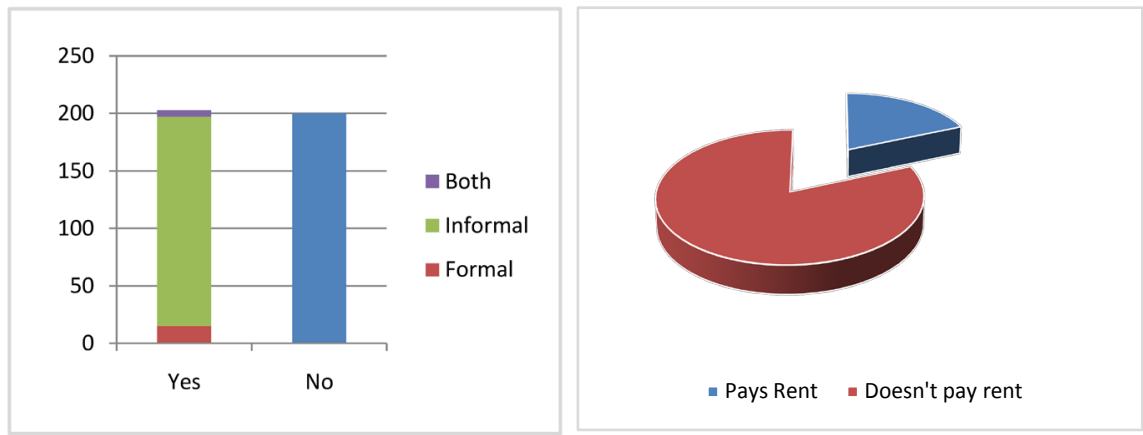

Figure 3. Loan and rental status of respondents. Source: Field Survey.

challenges. Challenges could be minimized based on the degree of impact on the financial aspect of a small business.

Survey shows only $6.7 \%$ of the respondent do not feel any challenges linked with the financial aspect of small business while $93.3 \%$ of the respondent feels different factors constraining the financial aspect of small business. In contrary to this situation, in the financial institutions of the US, the UK, France, Germany, and other European Union countries with bank loan mechanisms, personal and business loans do not require loan seekers to provide collateral to secure the loan (Worth, 2016; Silverman and Patterson, 2011; Blau, 2009).

The challenges were further classified into certain factors as $55.33 \%$ of respondents agreed that the challenges have arrived from lack of finance to operate daily business transactions. Similarly, $63.02 \%$ said that the challenges were mostly from competitive market whereas $41.93 \%$ of respondents faced the major challenges from the high interest in bank loans, $14.64 \%$ of respondents faced challenges from taxation policies, and finally $2.97 \%$ respondents faced challenges from other sectors which include internal as well as external factors. In this respect, Okpara \& Wynn (2007) asserted that small businesses can only thrive in a country with adequate infrastructures, such as an uninterrupted power supply and a well-developed road network, among other things.

To generate much-needed good jobs, small and medium-sized enterprises are crucial. In this respect, small businesses are indisputably important to the development of every nation's economy because they provide good employment and income source, contribute to the development of local technology, and foster indigenous entrepreneurs (Erdem and Erdem, 2011; Alaye-Ogan, 2012). Large companies must get involved to help SMEs and understand their potential.

Large businesses spend billions of dollars per year searching for other companies' goods and services, such as landscaping, cleaning services, transportation, software creation, food services, and office supplies. From the research conducted it was found that $27.7 \%$ of respondents responded that small businesses are highly affected by large-scale industries. $66.25 \%$ responded that large-scale industries moderately affect their business. $5.21 \%$ were neutral about such a situation, whereas $0.7 \%$ responded that small businesses were not affected by large-scale industries. 
Eventually, all successful small business startups face the problem of managing business expansion or growth. Market expansion is a phase of the life of a business that is rife with both possibilities and dangers. Business growth, on the one hand, often brings a corresponding increase in financial fortunes for both owners and employees. Among the survey conducted $34.73 \%$ of respondents faced the problem of financial issues while expanding the business. $80.6 \%$ faced the problem of space availability, $35.23 \%$ faced the problem of workforce issues and $10.42 \%$ faced the problem of marketing issues while expansion of business procedure. In this sense, Marlow \& Patton (2005) also contend that starting a small business is extremely risky and that the failure rate of small businesses in underdeveloped and developing countries is extremely high. Therefore, Akande (2011) contends that the success of a small business is heavily dependent on the skills, abilities, and personal attributes of the owner(s).

In operating a business, accounting plays a critical role because it helps you monitor sales and expenses, ensure statutory enforcement, and provide quantitative financial information to investors, management, and government that can be used in business decision-making. From the survey conducted, $27.79 \%$ of respondents responded that accounting knowledge highly affects small business and its fluent operation, $69.97 \%$ responded that accounting knowledge moderately affects their smooth operation of the business, and the rest of the responses were neutral about such scenario.

\subsection{Managerial Solution for Financial Hurdles in Small Business}

Out of these challenges, $97.27 \%$ of respondents have agreed that such challenges are manageable whereas the rest of $2.73 \%$ of respondents disagreed on being able to manage such issues. From the survey, it was found that out of 403 respondents, $23.82 \%$ of respondents agreed that better use of technology can help in overcoming challenges regarding financial aspects in small business. $62.77 \%$ of respondents agreed on better management of the supply chain can help in overcoming the mentioned challenges. 55.83\% picked better management of supply chain can help in overcoming mentioned challenges. 33.25\% of respondents agreed on effective training and development can help in enhancing business and overcoming challenges and $12.65 \%$ of respondents agreed on securing and managing funds can help in overcoming problems related to financial aspects. In this respect, Tushabomwe-Kazooba (2006) asserted in his study of the Ugandan towns of Bushenyi and Mbarara that 41 percent of respondents had received training with the majority of them receiving such training only after they had established the business. Whatever that can be in developing countries, Mwobobia (2012) contends that small businesses continue to account for a significant portion of industrial development in the developed world with playing specific roles in the economy that help to support and bolster a country's growth.

The Situation of Small Business Enterprises after the Pandemic. Since the outbreak of COVID-19, almost all the businesses have gone through a downfall 
in terms of financial aspects. $32.75 \%$ of respondents were highly affected by the pandemic. $65.75 \%$ of respondents were moderately affected whereas the rest of $1.49 \%$ of respondents were neutral about such situation. $32.75 \%$ of respondents answered that it was not safe to operate their business after the pandemic even though with safety and precaution whereas $71.25 \%$ of respondents answered that it was safe to operate their business after the pandemic even though with safety and precaution.

Post Pandemic Solutions: The major means that the respondents were considering to deal with the shortage of raw materials were mentioned where respondents had various factors to consider as reduction of production, outsourcing orders, increasing the procurement prices, seeking new procurement channels, delaying goods delivery, or no shortage of raw materials. Similarly, the main means respondents were considering to deal with the cash flow shortage were also asked where $2.48 \%$ out of 403 respondents loans by commercial banks, $16.12 \%$ were considering loans by microfinance companies or private individuals, $17.36 \%$ were considering negotiating with lenders to avoid withdrawing loans, $15.63 \%$ were considering reduction of operating costs which involves factors like layoffs and reduction in salary, etc. and finally $0.74 \%$ respondents had no cash shortfall problems.

\section{Conclusion}

Developing countries like Nepal have an old phenomenon in the scenario of small business enterprises. Small businesses include jobs for entrepreneurs, work for neighbors, and community meeting places. This paper offers insights into the different socio-demographic descriptions and financial aspects and their determinants. Most of the respondents were identified between 25 to 35 years of age. The majority of the respondents have university degrees (of both male and female).

The study reveals majority of people were facing the challenge in small business due to lack of financial accessibility. About 55 percent of respondents agreed that the challenges have arrived from lack of finance to operate daily business transactions. Similarly, 63 percent said that the challenges were mostly from competitive market, whereas around 42 percent of respondents faced the major challenges from the high interest in bank loans, negligible percent of respondents faced challenges from taxation and other sectors which include internal as well as external factors.

\section{Conflicts of Interest}

The authors declare no conflicts of interest regarding the publication of this paper.

\section{References}

Acharya, P. R. (2017). Small Businesses Create a Big Impact on the Economy.

https://thehimalayantimes.com/business/small-businesses-create-big-impact-economy/ 
Ackah, J., \& Vuvor, S. (2010). The Challenges faced by Small \& Medium Enterprises (SMEs) in Obtaining Credit in Ghana. Journal of Small Business Management, 38, 53-66.

Adhikari, D. B. (2019). Role of Micro-Finance in Socio-Economic Development of Kathmandu, Nepal. Patan Pragya, 5, 1-10. https://doi.org/10.3126/pragya.v5i1.30431

Adhikari, D. B., \& Shrestha, J. (2013). Economic Impact of Microfinance in Nepal: A Case Study of the Manamaiju Village Development Committee, Kathmandu. Economic Journal of Development Issues, 15 \& 16, 36-49. https://doi.org/10.3126/ejdi.v15i1-2.11861

Adhikari, D. B., Gupta, P., Devkota, N., Paudel, U. R., \& Parajuli, S. (2021). Challenges in Transformation of Informal Business Sector towards Formal Business Sector in Nepal: Evidence from Descriptive Cross-Sectional Study. Asian Journal of Agricultural Extension, Economics \& Sociology, 39, 95-106. https://doi.org/10.9734/ajaees/2021/v39i230534

Agbenyo, D. (2015). Challenges Facing Small and Medium Scale Enterprises (SMEs) in Accessing Credit (pp. 25-32). College of Humanities and Social Sciences, School of Business-Kwame Nkrumah University of Arts Science and Technology.

Akande, O. (2011). Accounting Skill as a Performance Factor for Small Businesses in Nigeria. Journal of Emerging Trends in Economics and Management Sciences, 2, 372-378.

Alaye-Ogan, E. (2012). A Practical Guide to Running Successful Small Businesses in Nigeria: Challenges, Peculiarities, and Effective Resolution Support. Deutschland: Lambert Academic Publishing.

Almus, M. (2004). The Shadow of Death-An Emperical Analysis of the Pre-Exit Performance of New German Firms. Small Business Economics, 23, 189-201. https://doi.org/10.1023/B:SBEJ.0000032033.00519.00

Blau, J. (2009). New Spurs for Europe's Small Firms. Research Technology Management, 52, 5-7.

Christina, B., Neelufer, A., \& Al Amri, S. (2014). Challenges and Barriers Encountered By the Smes Owners in Muscat. International Journal of Small Business and Entrepreneurship Research, 2, 1-13. https://www.eajournals.org/

Collis, J., \& Jarvis, R. (2002). Financial Information and the Management of Small Private Companies. Journal of Small Business and Enterprise Development, 9, 100-110. https://doi.org/10.1108/14626000210427357

Devkota, N., Budhathoki, A., Paudel, U. R., Adhikari, D. B., Bhandari, U., \& Parajuli, S. (2021). Online Trading Effectiveness in Nepal Share Market: Investors Awareness, Challenges, and Managerial Solution. Asian Journal of Economics, Business, and Accounting, 21, 90-98. https://doi.org/10.9734/ajeba/2021/v21i530385

Devkota, N., Paudel, U., \& Bhandari, U. (2020a). Tourism Entrepreneurs' Expectation from the Federal Government in Touristic City-Pokhara, Nepal. Journal of Hospitality and Tourism Insights, 3, 329-351. https://doi.org/10.1108/JHTI-06-2019-0082

Devkota, N., Paudel, U., \& Bhandari, U. (2020b). Does Westernization Influence in Business Culture of a Touristic City? Economics and Sociology, 13, 154-172. https://doi.org/10.14254/2071-789X.2020/13-4/10

Erdem, F., \& Erdem, S. (2011). Functional Strategies and Practices of Small and Medium-Sized Family Businesses. International Journal of Islamic and Middle Eastern Finance and Management, 4, 174-185. https://doi.org/10.1108/17538391111144506

Ghimire, R. (2011). Micro and Small Enterprises in Nepal Prospects and Challenges.

Ghimire, R. (2012). Micro and Small Level Enterprises in Nepal. (April). 
Hatten, T. S. (2012). Principles of Small Business Management. South-Western.

Hess, M. F., \& Cottrell, J. H. (2016). Fraud Risk Management: A Small Business Perspective. Business Horizons, 59, 13-18. https://doi.org/10.1016/j.bushor.2015.09.005

Karadag, H. (2015). Financial Management Challenges in Small and Medium-Sized Enterprises: A Strategic Management Approach. EMAJ: Emerging Markets Journal, 5, 26-40. https://doi.org/10.5195/EMAJ.2015.67

Karki, B. B. (2018). Practices of Micro Enterprises in Nepal. Journal of Nepalese Business Studies, 10, 20-27. https://doi.org/10.3126/jnbs.v10i1.19130

Kazimoto, P. (2014). Assessment of Challenges Facing Small and Medium Enterprises towards International Marketing Standards: A Case Study of Arusha Region Tanzania. International Journal of Academic Research in Accounting Finance and Management Sciences, 4, 303-311.

Kennedy, J., Tennent, B., \& Gibson, B. (2006). Financial Management Practices in Small Businesses: Regional and Metropolitan. Small Enterprise Research, 14, 55-63. https://doi.org/10.5172/ser.14.1.55

Kongolo, M. (2010). Job Creation versus Job Shedding and the Role of SMEs in Economic Development. African Journal of Business Management, 4, 2288-2295.

Lappalainen, J., \& Niskanen, M. (2013). Behavior and Attitudes of Small Family Firms towards Different Funding Sources. Journal of Small Business \& Entrepreneurship, 26, 579-599. https://doi.org/10.1080/08276331.2014.892309

Mambula, C. (2002). Perceptions of SME Growth Constraints in Nigeria. Journal of Small Business Management, 40, 58-65. https://doi.org/10.1111/1540-627X.00039

Marlow, S., \& Patton, D. (2005). The Financing of Small Businesses: Female Experiences and Strategies. In S. L. Fielden, \& M. J. Davidson (Eds.), International Handbook of Women and Small Business Entrepreneurship (pp. 66-77). https://doi.org/10.4337/9781845425586.00014

Minniti, M., \& Naudé, W. (2010). What Do We Know about the Patterns and Determinants of Female Entrepreneurship across Countries? The European Journal of Development Research, 22, 277-293. https://doi.org/10.1057/ejdr.2010.17

Moses, O. (2010). Understanding Business: The Basics. Jos: Matachers.

Moses, O., \& Adebisi, J. F. (2013). Small Business Financing in Nigeria: An Investigation of the Angel Option. Canadian Social Science, 9, 93-98.

Mutandwa, E., Taremwa, N. K., \& Tubanambazi, T. (2015). Determinants of Business Performance of Small and Medium-Sized Enterprises in Rwanda. Journal of Developmental Entrepreneurship, 20, 1550001. https://doi.org/10.1142/S1084946715500016

Mwobobia, F. M. (2012). The Challenges Facing Small-Scale Women Entrepreneurs: A Case of Kenya. International Journal of Business Administration, 3, 112.

https://doi.org/10.5430/ijba.v3n2p112

Ndiaye, N., Razak, L. A., Nagayev, R., \& Ng, A. (2018). Demystifying Small and Medium Enterprises' (SMEs) Performance in Emerging and Developing Economies. Borsa Istanbul Review, 18, 269-281. https://doi.org/10.1016/j.bir.2018.04.003

Nepal Rastra Bank (NRB) (2019). SMEs Financing in Nepal 2076. Kathmandu: Nepal Rastra Bank.

Okpara, J. O., \& Wynn, P. (2007). Determinants of Small Business Growth Constraints in a Sub-Saharan African Economy. SAM Advanced Management Journal, 72, 24.

Omar, S. S. bt., Arokiasamy, L., \& Ismail, M. (2009). The Background and Challenges Faced by the Small Medium Enterprises. A Human Resource Development Perspective. International Journal of Business and Management, 4, 95-102. 
https://doi.org/10.5539/ijbm.v4n10p95

Paudel, U. R., \& Devkota, N. (2018). Socio-Economic Influences on Small Business Performance in Nepal-India Open Border: Evidence from Cross-Sectional Analysis. Economics \& Sociology, 11, 11-30. https://doi.org/10.14254/2071-789X.2018/11-4/1

Paudel, U. R., \& Devkota, N. (2020). Harmonization of Socioeconomic Policy and Institutional Set-Up for Efficient Operation on Nepal-India Open Border Small Business. Journal of International Studies, 13, 108-122. https://doi.org/10.14254/2071-8330.2020/13-1/7

Persson, H. (2004). The Survival and Growth of New Establishments in Sweden, 1987-1995. Small Business Economics, 23, 423-440. https://doi.org/10.1007/s11187-004-3992-7

Ryan, T. (2017). The Factors Influencing SME Failure in South Africa. (February).

Savych, B. (2002). Development of Small and Medium Enterprises in Ukraine under Regulatory Constraints. Oakland, CA: Economics Education and Research Consortium.

Schlogl, H. (2004). Small and Medium Enterprises: Seizing the Potential. Organisation for Economic Cooperation and Development. The OECD Observer, 243, 46.

Silverman, R. M., \& Patterson, K. L. (2011). The Effects of Perceived Funding Trends on Non-Profit Advocacy: A National Survey of Non-Profit Advocacy Organizations in the United States. International Journal of Public Sector Management, 24, 435-451. https://doi.org/10.1108/09513551111147169

Tushabomwe-Kazooba, C. (2006). Causes of Small Business Failure in Uganda: A Case Study from Bushenyi and Mbarara Towns. African Studies Quarterly, 8, 27-35.

Worth, M. J. (2016). Fundraising. Principles and Practice. Thousand Oaks, CA: SAGE Publications. https://doi.org/10.4135/9781483393575

Yoshino, N. (2016). Major Challenges Facing Small and Medium-Sized Enterprises in Asia and Solutions for Mitigating Them. SSRN Electronic Journal, ADBI Working Paper 564. https://doi.org/10.2139/ssrn.2766242

Zaborek, P., \& Mazur, J. (2019). Enabling Value Co-Creation with Consumers as a Driver of Business Performance: A Dual Perspective of Polish Manufacturing and Service SMEs. Journal of Business Research, 104, 541-551.

https://doi.org/10.1016/j.jbusres.2018.12.067 